\title{
Anal Leiomyoma
}

National Cancer Institute

\section{Source}

National Cancer Institute. Anal Leiomyoma. NCI Thesaurus. Code C5608.

A well-circumscribed benign smooth muscle neoplasm arising from the anus. It is characterized by the presence of spindle cells with cig ar-shaped nuclei, interlacing fascicles, and a whorled pattern. 